\title{
Estimating wind power potential in multiple locations within mesoregion Fronteira Sul, Brazil
}

\author{
R. Treméa, D.D. Fabiane, J.M.V. Grzybowski \\ Universidade Federal da Fronteira Sul - UFFS \\ Av. Dom João Hoffmann, 313, CEP 99.700-000, Erechim, RS. \\ E-mail: jose.grzybowski@uffs.edu.br
}

\begin{abstract}
Fronteira Sul and its surroundings, the wind power potential is assessed by using the method of bins and the wind velocity data. The results are given in terms of average extractable power per square meter and index of serviceable winds for each of the sites and for the four seasons from Summer (2011/2012) to Spring (2012).
\end{abstract}

\section{Introduction}

As properly exploited, wind power can supply a substantial share of the actual load demand of electricity [1][2]. The attractiveness of wind power lies upon zero emission, abundant wind availability, low operational cost and scalability, among others, being suitable for applications ranging from extensive wind farms to residential standalone wind generators. Towards this end, a crucial requirement is the existence of practical data regarding wind energy potential in terms of existing wind regimes, thus showing how attractive wind energy looks like in a given location.

Nowadays in Brazil, 70,25\% of the installed capacity for electricity generation comes from renewable sources, most of it, 68,56\% from hydroelectric generators [3]. Wind power responds for $1,69 \%$ of the total installed capacity, which corresponds to $2,1 \mathrm{GWh}$ distributed in 96 wind power enterprises. Further, 93 other eolic projects under construction shall nearly double the installed eolic capacity in the next few years [3]. In this context of interest in eolic energy, prospective studies and investments were directed to large wind farms in spots featuring highest average velocities.

An alternative to large wind farms, microgeneration stands as a possibility to spread production and reduce dependence upon base load, thus weaving a increasingly decentralized electrical grid and allowing electricity to reach isolated communities that are not reached by the countrywide interconnected electrical system. Towards this end, a crucial requirement is the existence of practical studies regarding wind energy potential in terms of existing wind regimes and turbines, thus showing how attractive wind energy looks like from the viewpoint of microgeneration [4].

In this paper, we consider wind velocity data from 16 locations within mesoregion Fronteira Sul to provide estimates of average power potential per square meter and index of serviceable winds. The mesoregion Fronteira Sul encompasses 396 municipalities of the three southern Brazilian states and it has 3,9 million inhabitants in 121 thousand square kilometers.

\section{Materials and methods}

The wind velocity data were collected by meteorological stations of INMET (Instituto Nacional de Meteorologia) and they consist of mean velocities of samples obtained by measuring wind velocity for 10 minutes during every hour at the height $h=10$ meters. The data used in this study corresponds to the Summer (2011/2012) and Autumn, Winter and Spring (2012). For each season and site, the original wind data from 10 meters, $v_{10}$, were extrapolated to the height $h=12$ by means of the theoretical-empirical equation

$$
v_{h}=v_{10}\left(0,234+0,656 \log _{10}(h+4,75)\right)
$$


such that $v_{h}$ is the estimated velocity at height $h$ [5], which corresponds to a reasonable height of the hub for a small-scale wind turbine. The wind velocity data were separated into $N$ bins of width $w_{j}$ and midpoints $m_{j}$. The frequency, i.e., the number of occurrences in each bin, is denoted $f_{j}$ and the number of wind velocity readings equals

$$
n=\sum_{j=1}^{N} f_{j}
$$

The long-term average wind power per square meter (in $W / \mathrm{m}^{2}$ ) is given by

$$
\bar{P}=\frac{1}{2 n} \rho \sum_{j=1}^{N} m_{j}^{3} f_{j}
$$

where $\rho$ is the density of air. Note that equation (3) represents the average power available in the moving mass of air per unit area. From the Betz limit [6], recall that the theoretical limit of extractable power from the wind is $16 / 27$ of the total available power, that is,

$$
\bar{P}=\frac{16}{54 n} \rho \sum_{j=1}^{N} m_{j}^{3} f_{j}
$$

We highlight average extractable power as distinct from average available power, from equation (3). In the study, we consider $v_{\text {cut-in }}=2.2 \mathrm{~m} / \mathrm{s}$, which roughly corresponds to the starting windspeed of a small-scale wind generator, such as Verne 555 [7].

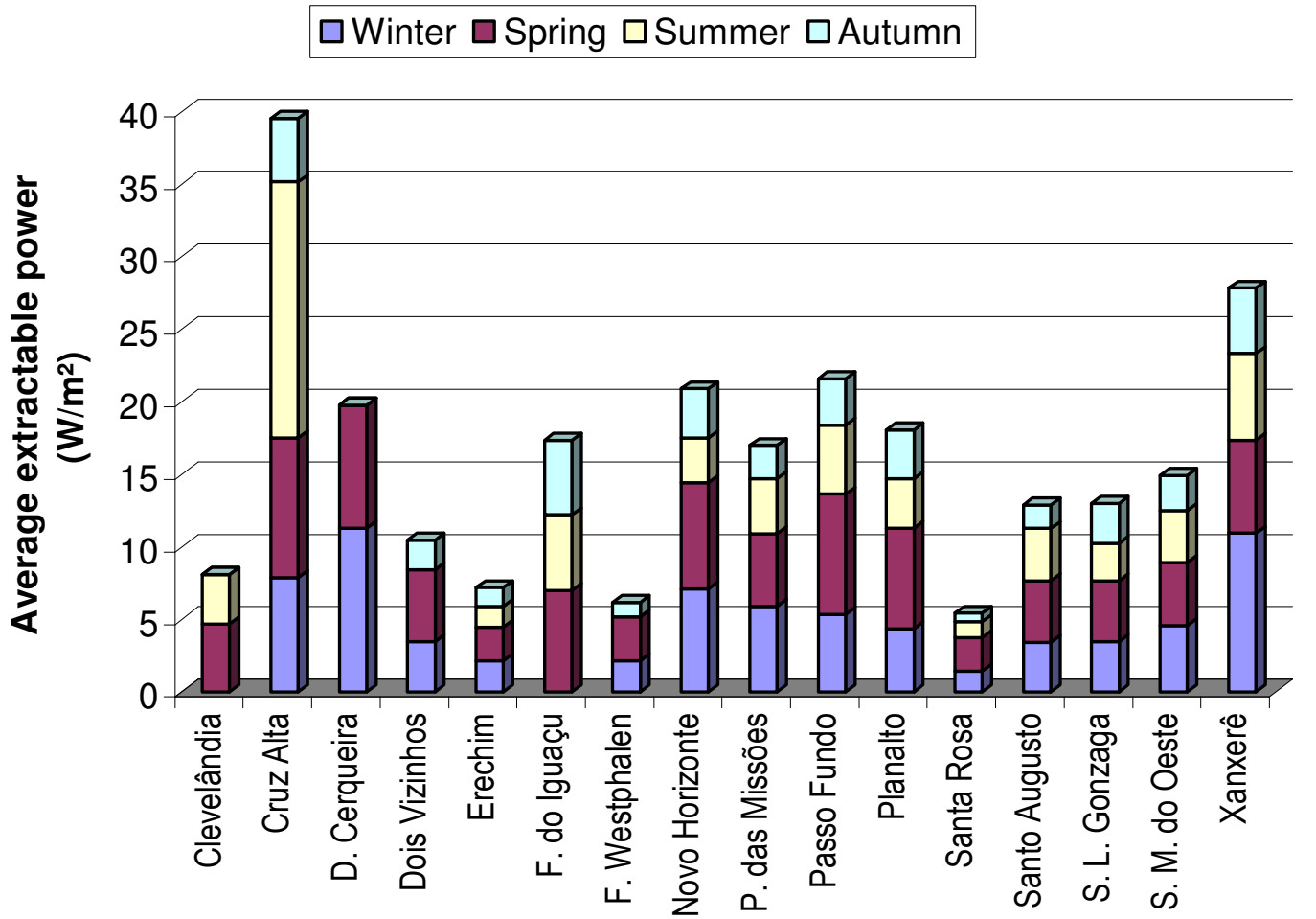

Figure 1 - Maximum extractable power per square meter for the wind regimes in Fronteira Sul for each season. Missing data for Clevelândia (Winter and Autumn), Dionísio

Cerqueira (Summer and Autumn), Dois Vizinhos (Summer), Foz do Iguaçu (Winter) and F. Westphalen (Summer).

\section{Results}

The average extractable power per season for a year is shown in Figure 1. The figure shows a large variation of average extractable power along the year, with largest values occurring during 
the Spring, then Winter. Considering such extract allows wind power to be thought in combination to other power sources, e.g., solar heating, solar photovoltaic, which experience peak production during a different season of the year, i.e., Summer. Considering the sites with largest average wind velocities, such as Cruz Alta, Xanxerê, Novo Horizonte, Passo Fundo and Planalto, further studies demonstrate that small-scale wind generators such as Verne 555 [7], Bergey Excel 5 [8], Bergey Excel 10 [9] or XZeres 442SR [10] could potentially deliver over $1.000 \mathrm{kWh}$ during each season of the year. Such amount of energy yield annual amounts comparable to the consumption of a couple Brazilian households $(\approx 150 \mathrm{kWh} /$ month $)$.

The authors thank CNPq for the support.

Keywords: wind speed distribution, output power, wind energy production, small-scale wind generators, Fronteira Sul.

\section{References}

[1] X. Lu, M.B. McElroy, J. Kiviluoma, Global potential for wind-generated electricity, Proc. National Academy of Science, vol. 106, number 27, pages 10933-10938, (2009).

[2] M.Z. Jacobson, M.A. Delucchi, A path to sustainable energy by 2030, Scientific American, November, pages 58-65, (2009).

[3] BIG - Banco de Informações de Geração. Capacidade de geração do Brasil. Available in http://www.aneel.gov.br/aplicacoes/capacidadebrasil/capacidadebrasil.cfm.

[4] A. N. Celik, Energy output estimation for small-scale wind power generators using Weibullrepresentative wind data, Journal of Wind Engineering and Industrial Aerodynamics 91, 693707, 2003.

[5] E.P. da Silva, Energia eólica: considerações teóricas e aplicação prática, Revista Tecnologia, number 13, (1992).

[6] J.F. Manwell, J.G. McGowan, A.L. Rogers, Wind energy explained - theory, design and application, John Wiley \& Sons, 2002.

[7] Aerogerador Verne555: Manual do produto. Available in www.enersud.com.br/wpcontent/.../manual_produtos_verne555_web.pdf. Access in June, 06th, 2013.

[8] Bergey Excel 5 Brochure. Available in http://bergey.com/documents/2012/05/excel-5-specsheet.pdf. Access in June, 06th, 2013.

[9] Bergey Excel 10 Brochure. Available in http://bergey.com/documents/2012/05/excel-10brochure.pdf. Access in June, 06th, 2013.

[10] XZeres Machines Brochure. Available in http://energysmartcompany.com/files/media/xzereswind-turbines/1429-XZERES-Brochure-6-21-2011-Low.pdf. Access in June, 06th, 2013. 